\title{
Crested Wheatgrass Vigor as Affected by Black Grass Bug and Cattle Grazing
}

\author{
R. JAMES ANSLEY AND C.M. MCKELL
}

\section{Abstract}

Light to moderate populations (50-200 per $\mathrm{m}^{2}$ ) of black grass bugs in a seeded monoculture of crested wheatgrass appeared to reduce plant vigor. Vigor of ungrazed plants was compared to plants grazed only by black grass bugs and plants grazed by black grass bugs and cattle. Generally, vigor decreased as levels of grazing increased. Leaf length, seedhead height, root crown nonstructural carbohydrates, and plant color correlated positively with vigor while functions of axillary tillering such as basal area and seedhead density correlated negatively with vigor. Cattle grazing was not in excess of intensities recognized as proper for the area.

Black grass bugs (Labops hesperius Uhler) are an important factor in some intermountain area rangeland ecosystems(Bohning and Currier 1967, Todd and Kamm 1974, Haws 1978). Apparently the insect is native to the West, having been sighted in some western states as early as 1870 . However, since the acreage of seeded, largely monocultural wheatgrass (Agropyron sp.) stands has increased, the insects have expanded greatly in number and range (Bohning and Currier 1967, Jensen 1971). Areas seeded to grass provide an optimum habitat for the insect because food is abundant and reproductive conditions are favorable, while natural predators such as spiders find the grass monoculture generally unsuitable.

The life cycle of the black grass bug begins usually in late March after snow melt and lasts about 3 months. Only one generation is produced per year and the insects overwinter as eggs (Todd and Kamm 1974). Greatest feeding intensity occurs during the adult stage which lasts from late April to the end of June (Bowers 1976).

The black grass bug appears to favor cool-season grasses such as crested wheatgrass (Agropyron cristatum) when feeding and damages plant tissue by piercing cell walls of leaves and stems and removing intercellular liquids (Haws 1978). The effect of the insect on photosynthetic capacity could be significant because of this feeding characteristic. Jensen (1971) noted that the insect can give wheatgrass fields a straw colored appearance during critical spring growth periods. Moderate to heavy populations of black grass bugs $\left(100+\right.$ per $\left.\mathrm{m}^{2}\right)$ have also reduced total dry weight production, digestibility, nutritional value, and palatability (Bohning and Currier 1967, Todd and Kamm 1974, Higgins et al. 1977). Lower populations (less than 100 per $\mathrm{m}^{2}$ ) did not significantly affect dry herbage yield or digestibility (Malechek et al. 1977).

Herbage production, digestibility, nutritional value, and palatability all reflect forage value of the plant but may not be the best indices for determining plant vigor (Mueggler 1975, Cook 1977). This study measured effects of black grass bugs on crested wheatgrass characteristics such as vertical and lateral growth, density of growth, plant color, carbohydrate reserves, and phenology which may provide an indication of how the insect affects plant vigor. A

\footnotetext{
Authors are graduate research assistant, Plant Science Division, University of Wyoming, Laramie 82071 , formerly a graduate research assistant, Range Dept., Utah Statc University, Logan 84322; McKell is a former USU professor and is presently working for Native Plants Inc., 360 Wakara Way, Salt Lake City, Utah 84108.

Grateful acknowledgement is extended to Dr. Austin Haws, who provided assistance in making these field plots available for study. This study was supported by Exp. Sta. Project No. 823 and by a grant from the Four Corners Regional Commission. Manuscript received December 29, 1980.
}

reduction in vigor could ultimately affect community characteristics such as trend, condition, and grazing capacity (Cook 1977).

\section{Materials and Methods}

The study was conducted from September 1976 to May 1978 on the Sterling Ranch in Diamond Fork Canyon, located east of Spanish Fork, Utah. The elevation and annual precipitation are $1700 \mathrm{~m}$ and $40 \mathrm{~cm}$, respectively. The study area was seeded to a monoculture of crested wheatgrass in 1965.

The experimental design consisted of three different treatments: ungrazed control, insect-grazed, and insect/livestock-grazed. The ungrazed treatment consisted of five fenced exclosures (constructed by the U.S. Forest Service in December, 1974) (each 25 $\mathrm{m}^{2}$ ) treated each spring with Temik, a granual systemic insecticide $\left(\mathrm{C}_{7} \mathrm{H}_{14} \mathrm{~N}_{2} \mathrm{O}_{2} \mathrm{~S}\right.$ ), at the rate of $187.5 \mathrm{~g} / .25 \mathrm{~m}^{2}$ (Union Carbide Corp. 1975). The insect-grazed treatment consisted of five fenced exclosures without Temik treatment. Five unfenced areas (each $25 \mathrm{~m}^{2}$ ) on open rangeland represented the insect/livestock-grazed treatment.

Strips of sheet metal $30 \mathrm{~cm}$ high were attached to the base of the fenced exclosures to keep rodents out of the exclosures. However, it was noticed that the rate of snow melt in the spring was reduced in areas adjacent to the metal strips. This increased moisture availability for plants growing near the fence. Therefore, all sampling was done at least one meter away from the fence.

Vertical and lateral growth were measured in te rms of leaf length $(\mathrm{cm})$, seedhead height $(\mathrm{cm})$, basal area $\left(\mathrm{cm}^{2}\right)$, and density of growth. Leaf length and seedhead height were measured at 2-week intervals during the fall of 1976 and spring through fall of 1977 . Six plants were chosen at random in each exclosure each time leaf length and seedhead height were measured. Leaf length and seedhead height were measured from the root crown to the tip of the longest leaf and tip of the highest seedhead respectively. Leaves were straightened to their full length when measured. Only one leaf and seedhead were measured per plant. Basal areas of the plants were measured once in the spring of 1978. Six plants were chosen at rand om in each exclosure for measu rement. Density of growth was estimated by measuring seedhead quantities per plant. Seedhead density was measured once in the summer of 1977 after seedheads for all plants in all treatments were fully developed. Six measurements per exclosure were taken.

Crested wheatgrass root crown nonstructural carbohydrates (RCNC) were measured as an indication of reserve sugar levels because they are the main storage site of nonstructural carbohydrates in this species and are subject to the least amount of short term variation (White 1973). Root crown tissue was collected from live plants, washed free of soil in cold water, and maintained in $85 \%$ ethanol until analysis. The samples were oven dried at $50^{\circ} \mathrm{C}$ for 48 hours and ground in a Pika mill to a fine powder. Crested wheatgrass stores RCNC in the form of short chain fructosans which undergo nearly 100\% hydrolysis in a mild acid (Smith 1969). Therefore, $0.5 \mathrm{~g}$ samples ( 5 samples per exclosure) were refluxed in $50 \mathrm{ml} 0.2 \mathrm{~N}$ sulfuric acid at $100-105^{\circ} \mathrm{C}$ for 1 hour to separate RCNC from structural material (Smith et al. 1964). Samples were 
filtered (Whatman No. 2). neutralized with $2 \mathrm{ml} \mathrm{30 \%} \mathrm{NaOH}$ and brought to a final volume of $100 \mathrm{ml}$ with $\mathrm{H}_{2} \mathrm{O} .1 \mathrm{ml}$ of sample solution was added to $2 \mathrm{ml}$ dinitrosalicyclic acid reagent and boiled in a water bath 15 minutes. After cooling, samples were diluted with $5 \mathrm{ml} \mathrm{H}_{2} \mathrm{O}$. Within 1-2 hours after boiling, color intensities were measured with a Beckman Model DU Spectrophotometer at $540 \mathrm{mu}$ and compared to glucose standards. Values were reported in milligrams RCNC per gram dry weight of root crown material. The acid reagent was prepared by dissolving (with warming) $5 \mathrm{~g}$ 3,5-dinitrosalicyclic acid in $100 \mathrm{ml} 2 \mathrm{~N} \mathrm{NaOH}$. This solution was mixed with a 60 percent potassium-sodium tartrate solution (prepared by dissolving $150 \mathrm{~g}$ in $250 \mathrm{ml} \mathrm{H}_{2} \mathrm{O}$ with warming). $\mathrm{H}_{2} \mathrm{O}$ was added to make a final volume of $500 \mathrm{ml}$.

The phenology of crested wheatgrass and the stages of the black grass bug life cycle were recorded at 2-week intervals from spring to fall. Plant color, a general indicator of photosynthetic activity, was estimated by visual observation during late summer and fall. Color was ranked according to the percentage of the whole plant which appeared green. Rankings were 0-25, 25-50, 50-75, and 75-100\% green.

Leaf length, seeded height, basal a rea, density of growth, RCNC reserves and plant color were evaluated statistically by analysis of variance (completely randomized design with subsampling). Comparisons of treatment means at each sampling date were accomplished by Duncan's Mean Comparison test (Steel and Torrie 1980).

Black grass bug population densities outside the exclosures averaged between 50 to 100 bugs per $\mathrm{m}^{2}$ in the spring of 1977. One of two black grass bugs per meter ${ }^{2}$ were found in the Temik treated exclosures. Black grass bugs were observed to be the predominant insect at the site. No insect population data were taken in 1976. However, Browsers (1976) found 200 black grass bugs per $\mathrm{m}^{2}$ in early June 1975 and Malechek et al. (1977) found between 30 and 156 insects per $\mathrm{m}^{2}$ in early June 1974.

Cattle grazing at the ranch was managed by the U.S. Forest Service from 1965 to 1977 . Grazing data are shown in Table 1. Herbage production at Sterling Ranch is about $1700 \mathrm{~kg} / \mathrm{ha}(1500$ $\mathrm{lb} /$ acre) annually (Malechek et al. 1977). Proper use (33\% total production) is the refore $560 \mathrm{~kg} / \mathrm{ha}$ or, about $1.54 \mathrm{AUM}$ per hectare (assuming one AUM requires $363 \mathrm{~kg}$ air dry forage). Proper use was exceeded only 1969 (Table 1).

Table 1. Cattle grazing intensities at Sterling Ranch' from 1966 to 1978.

\begin{tabular}{lccl}
\hline \hline Year & $\begin{array}{c}\text { AUM } \\
\text { level }\end{array}$ & $\begin{array}{c}\text { Grazing Use } \\
(\text { AUM ha }\end{array}$ & Grazing duration \\
\hline 1966 & 0 & 0 & Pasture was rested \\
1967 & 111 & .65 & June 6-June 25 \\
1968 & 83 & .49 & June 6-June 25 \\
1969 & 577 & 3.39 & June 6-July 1 \\
1970 & 253 & 1.49 & June 8-June 20 \\
1971 & 167 & .98 & Sept. 18-Sept. 27 \\
1972 & 194 & 1.14 & June 10-June 22 \\
1973 & - & - & Fall roundup only \\
1974 & 107 & .63 & June 15-June 25 \\
1975 & - & - & Fall roundup only \\
1976 & 186 & 1.09 & June 3-July I \\
1977 & - & - & Fall roundup only \\
\hline
\end{tabular}

'The pasture at Sterling Ranch is 170 hectares.

Precipitation data for spring and summer of 1977 showed that April and the first part of May were rather dry $(2.54 \mathrm{~cm}$ total). A wet period occurred during the last two weeks of May $(7.19 \mathrm{~cm})$ and was followed by a very dry period throughout June $(0.30 \mathrm{~cm})$. A normal amount of precipitation for the area occurred during July $(3.48 \mathrm{~cm})$ and August $(4.0 \mathrm{~cm})$. September was usually dry $(2.88 \mathrm{~cm})$. No precipitation data were available before October 1976. Precipitation from October to December 1976 was $2.69 \mathrm{~cm}$.

\section{Results and Discussion}

Effects of the Black Grass Bug Alone

Comparisons between crested wheatgrass phenology and the
Table 2. Comparison of crested wheatgrass phenology to the life cycle the black grass bug at Sterling Ranch in 1977.

\begin{tabular}{lll}
\hline \hline Crested wheatgrass & Date & Black grass bug \\
\hline First leaf stage & $\begin{array}{l}\text { March 20 } \\
\text { April 1 } \\
\text { April 10 } \\
\text { April 20 } \\
\text { May 5 } \\
\text { May 16 }\end{array}$ & $\begin{array}{l}\text { Eggs hatched } \\
\text { Second instar } \\
\text { Third instar } \\
\text { Adult stage } \\
\text { Maximum adult } \\
\text { population } \\
\text { Adult population } \\
\text { decline }\end{array}$ \\
$\begin{array}{c}\text { Fourth leaf stage/ } \\
\text { Heading }\end{array}$ & June 4 & $\begin{array}{c}\text { All adults dead } \\
\text { Fifth leaf stage/ } \\
\text { Flowering }\end{array}$ \\
\begin{tabular}{c} 
Mature seed \\
\hline
\end{tabular} & June 25 & \\
\hline
\end{tabular}

black grass bug life cycle in 1977 show that the most active perio of crested wheatgrass growth (second leaf stage to flowering) we concurrent with the adult stage of the insect's life cycle (Table 2 This confirms earlier reports by Todd and Kamm (1974).

Some of the data suggest that the black grass bugs alone ha significant effects on crested wheatgrass vigor. Plants grazed on] by insects had significantly shorter leaf length $(22.7 \mathrm{~cm})$ tha ungrazed plants $(29.3 \mathrm{~cm})$ during the fall of 1976 (Table 3). In 197 leaf length was significantly shorter on plants grazed only $b$ insects $(27.4 \mathrm{~cm})$ than on ungrazed plants $(31.2 \mathrm{~cm})$ by June 2 when leaves were fully developed (fifth leaf stage; see Table 2 an 3). Relative differences in leaf length between insect-grazed plan and ungrazed plants remained essentially the same after June 2 although differences showed only trends and were not significat : $P<0.05$. Leaf length decreased in all treatments from August $10 \mathrm{t}$ September 27, 1977, probably because of leaf dessication an curling. Differences in leaf length between insect-grazed an ungrazed plants were not significant before June 25 except 0 April 1 when insect-grazed plants actually had longer leaves (8 $\mathrm{cm})$ than ungrazed plants $(6.3 \mathrm{~cm})$.

Table 3. Average leaf length of crested wheatgrass in 1976 and 1977.

\begin{tabular}{|c|c|c|c|}
\hline \multirow[b]{2}{*}{ Date } & \multicolumn{3}{|c|}{ Average leaf length $(\mathrm{cm})$} \\
\hline & Ungrazed plants & $\begin{array}{l}\text { Plants grazed } \\
\text { by insects }\end{array}$ & $\begin{array}{c}\text { Plants grazed } \mathrm{b} \\
\text { insects and } \\
\text { and livestock }\end{array}$ \\
\hline $\begin{array}{l}\text { (1976) Sept. 16 } \\
\text { (1977) April 1 } \\
\text { April } 29 \\
\text { May } 16 \\
\text { June } 4 \\
\text { June 25 } \\
\text { July 17 } \\
\text { August } 10 \\
\text { Sept. } 27\end{array}$ & $\begin{array}{r}29.3 \times \\
6.3 \times \\
16.5 \times \\
20.4 \times \\
26.0 \times \\
31.2 \times \\
30.9 \times \\
31.7 \times \\
26.7 \times\end{array}$ & $\begin{array}{l}22.7 \mathrm{y} \\
8.3 \mathrm{y} \\
17.2 \mathrm{x} \\
20.5 \mathrm{x} \\
26.4 \mathrm{x} \\
27.4 \mathrm{y} \\
28.2 \mathrm{xy} \\
28.6 \mathrm{xy} \\
23.9 \mathrm{x}\end{array}$ & $\begin{array}{r}15.9 \mathrm{z} \\
7.1 \mathrm{x} \\
15.2 \mathrm{x} \\
17.2 \mathrm{y} \\
22.2 \mathrm{y} \\
25.1 \mathrm{y} \\
25.8 \mathrm{y} \\
25.3 \mathrm{y} \\
19.8 \mathrm{y}\end{array}$ \\
\hline
\end{tabular}

'Means having the same letters are not significantly different $(P<0.05)$ between tre: ments within a particular sampling date (within rows).

Culm elongation in 1977 occurred primarily after floral initiz tion (Table 2 and Fig. 1). During elongation culms act as a carbr hydrate sink and import assimilates from leaf sources rather tha root storage tissue (Moser 1977). The degree of elongation an subsequent seedhead height may therefore be partially dependet on the amount of carbohydrates it imports from leaves. Hence, reduction in leaf photosynthetic capacity could adversely influenc stem elongation. Of course, other factors involved in elongatio such as hormone balance, light intensity, daylength, phytochrom balance, etc., should not be overlooked.

In this study seedhead height was significantly greater $\mathbf{i}$ ungrazed plants $(36.7 \mathrm{~cm})$ than insect-grazed plants $(28.6 \mathrm{~cm}) \mathrm{b}$ July 17 and remained significantly higher for the rest of th 


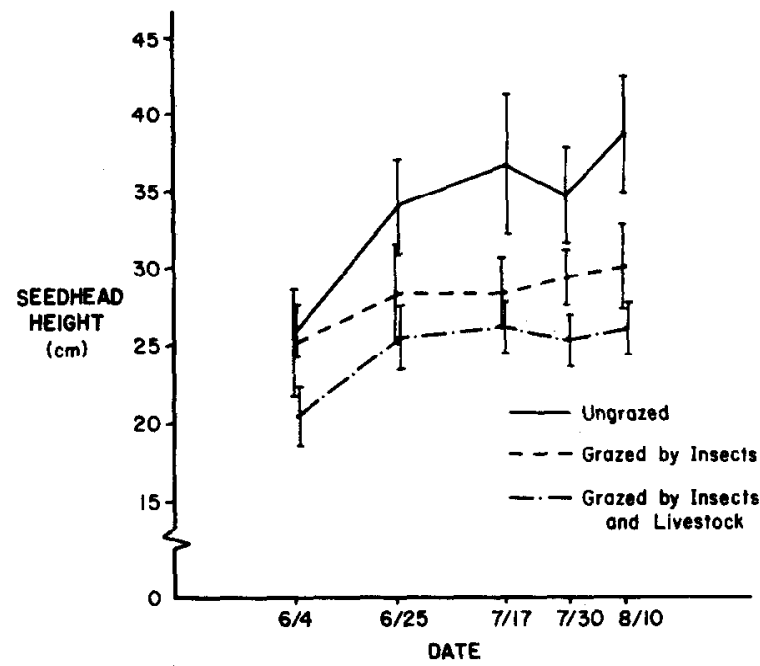

Fig. 1. Height of crested wheatgrass inflorescence at Sterling Ranch during the summer of 1977. Confidence intervals $(\mathbb{P}<0.05)$ have been placed on each treatment mean. Means with overlapping confidence intervals are not significantly different during a particular sampling date.

summer (Figure 1). Seedhead height showed trends of being higher in ungrazed plants than insect-grazed plants during both June sampling dates.

RCNC reserves were generally higher for plants in all three treatments during September than in April (Fig. 2). This agrees with Cook (1966) who found crested wheatgrass carbohydrate reserves were lower during leaf development in the spring than during fall dormancy.

At the onset of fall dormancy in September 1976 and September 1977 RCNC reserves were lower in insect-grazed plants than in ungrazed plants although differences were not significant at $P<0.05$ (Fig. 2). Differences between these two treatments were significant at $P<0.10$ on both September sampling dates, however. RCNC reserves were essentially the same between insect-grazed (120.9 $\mathrm{mg} / \mathrm{g}$ ) and ungrazed plants (122.7 mg/g) on April 1. RCNC reserves were significantly greater in insect-grazed plants (142.2 $\mathrm{mg} / \mathrm{g}$ ) than ungrazed plants (124.8 $\mathrm{mg} / \mathrm{g})$ on August 10.

\section{Black Grass Bug and Livestock Effects}

The combined effect of black grass bug and cattle grazing on crested wheatgrass also appeared to be detrimental to vigor and, in many instances, reduced vigor more than insect grazing alone. In the fall of 1976 and on all sampling dates after April 29 in 1977, leaf

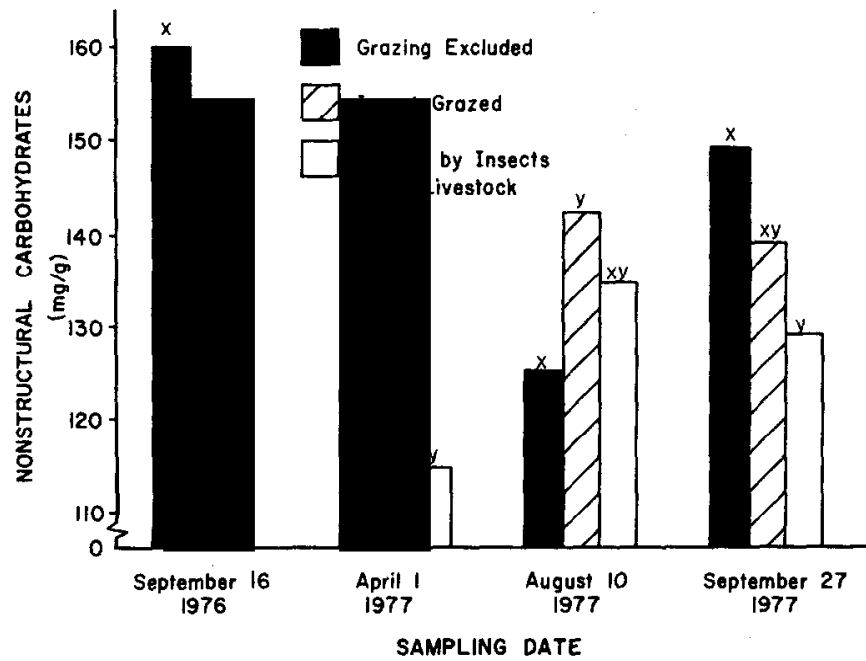

Fig. 2. Root crown nonstructural carbohydrate (RCNC) reserve levels of crested wheatgrass when exposed to three kinds of grazing stress. Means having the same letters are not significantly different $(\mathrm{P}<0.05)$ during $a$ particular sampling date. length was significantly shorter on insect/livestock-grazed plants than on ungrazed plants (Table 3). There were no significant differences in leaf length between insect/livestock-grazed plants and ungrazed plants in April 1977, however. Leaf length was significantly shorter on insect/livestock-grazed plants than on plants grazed only by insects in September 1976 and late May, early June and September 1977 (Table 3). Leaf length was shorter for insect/livestock-grazed plants than insect-grazed plants on all other sampling dates (except April 1, 1977) although differences showed only trends and were not significant at $P<0.05$.

Seedhead height showed similar trends to leaf length when comparing the three treatment effects. Seedhead height was significantly lower in insect/livestock-grazed plants than ungrazed plants on all sampling dates in 1977 (Fig. 1). Seedhead height was significantly lower in insect/livestock-grazed plants $(25.1 \mathrm{~cm})$ than insect-grazed plants $(29.3 \mathrm{~cm})$ on July 30 and showed trends of being lower in insect/livestock-grazed plants than insect/grazed plants on all other sampling dates although these differences were not significant at $P<0.05$. It is interesting to note that culm elongation from June 25 to August 10 in ungrazed plants was $4.8 \mathrm{~cm}$ while only $1.4 \mathrm{~cm}$ and $0.6 \mathrm{~cm}$, respectively in insect-grazed plants and insect/ livestock-grazed plants was only $1.4 \mathrm{~cm}$ and $0.6 \mathrm{~cm}$, respectively. Perhaps this is another indication of better vigor in ungrazed plants.

RCNC reserves were significantly lower in insect/livestockgrazed plants than ungrazed plants in both the April 1 and September 27 sampling dates (Fig. 2). Insect/livestock-grazed plants actually had a higher RCNC level than ungrazed plants on August 10 although this difference was not significant $(P<0.05)$. On both April 1 and September 27, 1977, insect/livestock-grazed plants had lower RCNC levels than insect-grazed plants although these differences were not significant at $P<0.05$. August 10 data showed no significant difference in RCNC levels between plants in the two grazed treatments although insect-grazed plants had slightly higher levels.

In summary, leaf length and seedhead height became shorter and lower with increased grazing except during early spring sampling dates. Differences in leaf length and seedhead height were generally greater between ungrazed plants and insect-grazed plants than between insect-grazed plants and insect/livestock-grazed plants. It was apparent that insects alone had an effect. RCNC reserves generally decreased with increased grazing except during the August 10 sampling date.

\section{Phenological Acceleration}

Results from Table 4 show that ungrazed plants were significantly greener than insect/livestock-grazed plants on all sampling dates and were significantly greener than insect-grazed plants on all dates except September 27. Insect-grazed plants showed trends of being greener than insect/livestock-grazed plants on all sampling dates although differences were not significant at $P<0.05$. These results, like leaf length and seedhead height, show greater differences between ungrazed and insect-grazed plants than between insect-grazed and insect/livestock-grazed plants.

Generally, Table 4 results suggest that ungrazed plants remained greener for a longer period of time than plants in grazed treatments and, that insect-grazed plants remained greener for a longer period

Table 4. Percent of overall greenness of erested wheatgrass during late summer and fall of 1977 .

\begin{tabular}{lccc}
\hline Date & Ungrazed plants & $\begin{array}{c}\text { Plants grazed } \\
\text { by insects }\end{array}$ & $\begin{array}{c}\text { Plants grazed by } \\
\text { insects and } \\
\text { livestock }\end{array}$ \\
\hline July 30 & $73.0 \mathrm{x}^{\prime}$ & $45.0 \mathrm{y}$ & $35.0 \mathrm{y}$ \\
August 10 & $64.0 \mathrm{x}$ & $33.0 \mathrm{y}$ & $21.0 \mathrm{y}$ \\
September 12 & $44.0 \mathrm{x}$ & $21.0 \mathrm{y}$ & $16.0 \mathrm{y}$ \\
September 27 & $31.0 \mathrm{x}$ & $19.0 \mathrm{xy}$ & $14.0 \mathrm{y}$ \\
\hline
\end{tabular}

${ }^{1}$ Means within similar letters are not significantly different $(P<0.05)$ between treatments within a particular sampling date (within rows). 
of time than insect/livestock-grazed plants. Differences, of course, became less apparent in late September as plants in all treatments became less photosynthetically active. These results suggest that plants in the grazing treatments were accelerated in their phenological development and entered into late summer quiescence earlier than ungrazed plants. Insect/livestock-grazed plants showed trends of being more phenologically accelerated than insect-grazed plants.

Phenological acceleration of grazed plants explains why leaf length was shortest for ungrazed plants in early spring 1977 , but increased in June and was longest in ungrazed plants by June 25 (Table 3). Acceleration in grazed plants also explains why RCNC reserves increased for plants in the two grazed treatments before August 10 (see Fig. 2), but did not increase in ungrazed plants until after the August 10 sampling date. RCNC results show along with Cook (1966), White (1973), Cook (1977), and many others that RCNC reserves can be used to determine grazing impact and plant vigor. However, comparisons should not be made of plants in different phenological stages or results could be misleading. Other parameters of plant activity should be used in addition to carbohydrate reserves to accurately assess vigor (Cook 1977).

\section{Seedhead Density and Basal Area}

Seedhead density increased with increased grazing (Table 5). Insect/livestock-grazed plants had significantly more seedheads per plant than insect-grazed and ungrazed plants. Insect-grazed plants had significantly more seedheads per plant than ungrazed plants.

Insect/livestock-grazed plants showed a significant increase in basal area over the ungrazed control. The study assumed that basal areas of all plants were equal in 1974 before the exclosures were constructed. No base data were taken during 1974 to confirm the assumption, however. Three growing seasons occurred between the time of exclosure construction and basal area measurement. Only 1976 had substantial cattle grazing (see Table 1). Several studies have shown that basal areas of bunchgrasses can increase within 1 to 3 years after grazing or clipping treatment (Jameson 1963, Vogel and Van Dyne 1966, Trlica 1977). Ward and Blaser (1961) found tillering in orchardgrass increased by $7-10$ new tillers per shoot one month after defoliation. Of course, none of these studies observed insect effects on tillering. It appears from this study that black grass bugs affected tillering in such a way as to increase reproductive culm production but not basal area.

Results from these data suggest that grazed plants had terminal buds either removed or sufficiently damaged to induce lateral tillering. Black grass bugs did not affect tillering as much as cattle. Several studies have shown that the growth form of cool-season bunchgrasses is more or less perpendicular on ungrazed a reas, but grazing (by cattle or sheep) causes a more horizontal growth with more shoots and less total plant height (Hickey 1961, Vogel and Van Dyne 1966, Hyder 1972).

\section{Assessment of Crested Wheatgrass Vigor}

Vigor implies that a plant has an extra capacity to withstand environmental stresses and can respond readily to favorable growing conditions in terms of production (Cook 1977, Trlica 1977). Results from this study suggest that increased plant vigor may not be reflected by an increase in some plant production parameters. Parameters which are a function of tillering such as seedhead

Table 5. Number of seedheads per plant and basal area of crested wheatgrass in May, 1978.

\begin{tabular}{lccc}
\hline & Ungrazed plants & $\begin{array}{c}\text { Plants grazed } \\
\text { by insects }\end{array}$ & $\begin{array}{c}\text { Plants grazed by } \\
\text { insects and } \\
\text { and livestock }\end{array}$ \\
\hline $\begin{array}{l}\text { Seedheads per plant } \\
\text { Basal a rea }\left(\mathrm{cm}^{2}\right)\end{array}$ & $\begin{aligned} 14.7 \mathrm{a}^{\mathrm{l}} \\
436.0 \mathrm{x}\end{aligned}$ & $\begin{array}{r}30.8 \mathrm{~b} \\
428.6 \mathrm{x}\end{array}$ & $\begin{array}{r}63.5 \mathrm{c} \\
629.0 \mathrm{y}\end{array}$ \\
\hline
\end{tabular}

Means with similar letters are not significantly different within each row $(\mathcal{P}<0.05)$. density per plant and basal area are perhaps not good indicators of vigor because these parameters are more often a reflection of the plant's reaction to meristematic tissue removal or destruction than to the actual vigor of the plant. Mueggler (1975) and Hazell (1965) found that flower stalk number and density of growth in terms of leaf quantities were not reliable indexes to measure vigor. Hyder and Sneva (1959) found that removal of shoot apices stimulated tillering in crested wheatgrass but reduced dry matter yields. Cook (1977) suggested that some plants may increase seed production rather than form vegetative growth when they are in poor state of vigor.

Production parameters which are not directly a function of axillary tillering such as leaf length, seedhead height, and RCNC reserves are perhaps better indices of crested wheatgrass vigor. Many authors believe leaf length and plant height are the most consistent indicators of vigor (Johnson 1956, Hazell 1965, Mueggler 1975). As was mentioned earlier, carbohydrate reserves appear to be a reliable vigor index when making comparisons of plants in similar phenological stages. Generally, however, results from this study agree with Cook (1977) that no single production characteristic is believed to be a consistently reliable index of vigor and several characteristics should be observed before determining vigor.

\section{Summary and Conclusions}

Results suggest that black grass bugs alone have a deleterious impact on crested wheatgrass vigor by adversely affecting leaf length, seedhead height, and root crown carbohydrate reserves. Reductions in these parameters plus an accelerated plant phenology and the occurrence of the adult stage of the insect during the most active growth period of the plant may either cause or result from a decrease in photosynthetic capacity. Insect-grazed plants showed signs of more axillary tillering than ungrazed plants. This was interpreted as a sign of grazing stress and poor plant vigor.

Decreases in vigor became more apparent in all parameters measured when crested wheatgrass was exposed to combined black grass bug and cattle grazing even when cattle grazing intensities were not in excess of that recognized as proper for the area.

These results support other studies which suggest that black grass bug infestation can be a significant problem and merits further study in determining black grass bug effects both physiologically and ecologically. Further studies should include field measurements of plant respiration, analysis of chlorophyll content, ${ }^{14} \mathrm{CO}_{2}$ fixation rates, and carbohydrate storage analysis to determine more completely the effect of the insect on photosynthetic capacity. Some preliminary work has been initiated in this area by Weibe and Schimpf (Haws 1978).

More research is needed in the area of black grass bug control. Several authors have suggested Malathion (Temik is not acceptable as it is toxic to livestock) treatments or cultural management practices (Higgins et al. 1977, Kamm and Fuxa 1977, Dickerson 1978). Infestation may be avoided in future renovation projects if cool-season bunchgrasses are not seeded to monocultures. Control would appear to be economically feasible because in areas such as Sterling Ranch, plant vigor is being reduced even though cattle grazing has not been excessive.

Range managers should consider the density of black grass bugs and other insects before making conclusions regarding cause for changes in plant vigor and phenological development of crested wheatgrass-seeded rangelands.

\section{Literature Review}

Bohning, J.W., and .W.F. Currier. 1967. Does your range have wheatgrass bugs? J. Range Manage. 20:265-267.

Bowers, D.M. 1976. Insect consumption of seeded rangeland herbage in a selected area of Diamond Fork Canyon, Utah County, Utah. M.S. Thesis, Utah State Univ., Logan. 45 p.

Cook, C.W. 1966. Carbohydrate reserves in plants. Utah Agr. Exp. Sta., Utah Resources Series 31, 47 p. 
Cook, C.W. 1977. Effects of season and intensity of use on desert vegetation. Utah Agr. Exp. Sta. Bull. 483. Logan, 57 p.

Dickerson, G.W. 1978. Control of black grass bugs (Labops hesperius Uhler) in northern New Mexico. J. Range Manage. 31:398-399.

Haws, B.A. (Project Coordinator). 1978. Economic impacts of Labops hesperius on the production of high quality range grasses. Final report of Utah Agr. Exp. Sta. to Four Corners Reg. Comm., Logan, 269 p.

Hazell, D.B. 1965. Vegetative composition, forage production, and plant vigor as influenced by data of mowing. J. Range Manage. 18:261-264.

Hickey, W.C., Jr. 1961. Relation of selected measurements to weight of crested wheatgrass plants. J. Range Manage. 14:143-146.

Higgins, K.M., J.E. Bowns and B.A. Haws. 1977. The black grass bug (Labops hesperius Uhler): Its effect on several native and introduced grasses. J. Range Manage. 30:385-387.

Hyder, D.N. 1972. Defoliation in relation to vegetative growth. p. 304-317. In: Younger, V.B. and C.M. McKell (eds.). Biology and utilization of grasses. Academic Press, New York.

Hyder, D.N., and F.A. Sneva. 1959. Growth and carbohydrate trends in crested wheatgrass. J. Range Manage. 12:271-276.

Jameson, D.A. 1963. Responses of individual plants to harvesting. Bot. Rev. 29:532-594.

Jensen, F. 1971. Reseeding and Labops. Range improvement notes. U.S. Forest Serv. Intermt. Rep. 16:6-9. Ogden.

Johnson, W.M. 1956. The effect of grazing intensity on plant composition, vigor, and growth of pine-bunchgrass ranges in Central Colorado. Ecology 37:790-798.

Kamm, J.A., and J.R. Fuxa. 1977. Management practices to manipulate populations of the plant bug Labops hesperius Uhler. J. Range Manage. 30:385-387.

Malechek, J.C., A.M. Gray and B.A. Haws. 1977. Yield and nutritional quality of intermediate wheatgrass infested by black grass bugs at low population densities, J. Range Manage. 30:128-131.
Moser, L.E. 1977. Carbohydrate translocation in range plants. Chapter 2. In: Sosebee, R.E. (ed.). Rangeland plant physiology. Soc. Range Manage. Range Science Series No. 4. 290 p.

Mueggler, W.F. 1975. Rate and pattern of vigor recovery in Idaho fescue and Bluebunch wheatgrass. J. Range Manage. 28:198-204.

Smith, D. 1969. Removing and analyzing total nonstructural carbohydrates from plant tissues. Div. Coll. Agr. and Life Sci. Res. Rep. 41, Univ. Wisconsin, Madison, 11 p.

Smith, D., G.M. Paulsen, and C.A. Raguse. 1964. Extraction of total available carbohydrates from grass and legume tissue. Plant Physiol. 39:960-962.

Steel, R.G.D., and J.H. Torrie. 1980. Principles and procedures of statistics. McGraw-Hill Book Co., New York. 633 p.

Todd, J.G., and J.A. Kamm. 1974. Biology and impact of a grass bug Labops hesperius Uhler in Oregon rangeland. J. Range Manage. 27:453458.

Triica, M.J., Jr. 1977. Effects of frequency and intensity of defoliation on primary producers of arid and semi-arid rangelands. p. 27-55. In: The impact of herbivores on arid and semi-arid rangelands. Proceedings, 2nd United States/Australia Rangeland Panel, Adelaide, 1972. Australian Rangeland Society, Perth.

Union Carbide Corporation. 1975. Temik aldicarb pesticide. Salinas, Calif. $63 \mathrm{p}$.

Vogel, W.G., and G.M. Van Dyne. 1966. Vegetation responses to grazing management on a foothill sheep range. J. Range Manage. 19:80-85.

White, L.M. 1973. Carbohydrate reserves of grasses: A review. J. Range Manage. 26:13-18.

Ward, C.Y., and R.E. Blaser. 1961. Carbohydrate food reserves and leaf area in regrowth of orchardgrass. Crop Sci. 5:366-370.

\section{rangeland reference areas}

by

\section{William Laycock, Chairman \\ SRM Rangeland Reference Area Committee}

Society for Range Management 2760 West Fifth Avenue Denver, Colorado 80204
This third publication in the Range Science Series reviews the published literature dealing with rangeland reference areas, summarizes current programs of other groups in the United States and Canada who are interested in natural area preservation, lists activities in other countries, and outlines a program useful for encouraging preservation of reference areas. Rangeland Reference Areas is of particular value to those interested in range research as well as preservation of reference areas and would be an excellent supplementary text for range students at the college level.

- soft cover $\bullet 72$ pages $\bullet$ illustrated $\bullet$ bibliography $\bullet \$ 2.00$ postpaid 